\title{
Voices of Gender Discrimination: A Feminist Stylistic Analysis of Khaled Husseini's A Thousand Splendid Suns
}

\section{R. N. Khan (Rab Nawaz Khan)', T. Khan (Tariq Khan)², A. Naz (Arab Naz)³}

1 Assistant Professor, Abdul Wali Khan University Mardan, Pakistan.

Original Article

2 Assistant Professor, University of Malakand, Pakistan.

3 Professor/Dean, Faculty of Social Sciences, University of Malakand, Pakistan.

\section{E-mail address:}

rnawaz81@yahoo.com

\section{Reprint address:}

Rab Nawaz Khan

Abdul Wali Khan University Mardan

Pakistan

Source: Clinical Social Work and Health Intervention

Pages: $79-85$
Volume: 10

Issue: 3

\section{Reviewers:}

Steve Szydlowski

University of Scranton school of education, USA

Roberto Cauda

Institute of Infectious Diseases, Catholic University of the Sacred Heart, Rome, IT

\section{Keywords:}

Sexism. Feminist Stylistics. Tribalism. Ideological Extremism. Patriarchy.

\section{Publisher:}

International Society of Applied Preventive Medicine i-gap

CSWHI 2019; 10(2): 79 - 85; DOI 10.22359/cswhi_10_3_08 @ 2019 Clinical Social Work and Health Intervention

\section{Abstract:}

This paper is an attempt to investigate feminist stylistic analysis about various voices of gender discrimination in Khaled Hosseini's A Thousand Splendid Suns 2007. It unveils the female characters' attempts of resistance to such discriminatory practices and their underlying ideologies. The novel

is a chronological narration of the Afghan people beset by their domestic and socio-political issues. However, gender discrimination (or sex- 
ism) against the Afghan women at the domestic, social and institutional levels is a dominant thematic issue. The major characters in the novel provide a strong base for various causes of the issue, and their subsequent implications of gender discrimination in different ethnic, ideological and institutional backgrounds. The study highlights not only the linguistic resources, but also the social and institutional underpinnings of gender discrimination. It reveals that the linguistic resources for gender discrimination include attributive, dehumanizing, belittling, oppressing and sexist terms and expressions.

\section{Introduction}

Current studies on gender and language are interdisciplinary as they cross boundaries of linguistics into women/gay studies, literature and social sciences (Sunderland, 2006). Gender discrimination (or sexism) is a social practice of discrimination realized in language use that works against women on the basis of gender differences. Van Dijk, (2005, p. 2) views sexism as "domination of women by men and on the basis of constructed gender differences." Sexism is viewed at the discursive, cultural and socio-cognitive dimensions as attitudes and beliefs of sexism are shared and shaped by sexist discursive encounters. Lazar (2007) considers gender as an ideological social structure, causing people's dichotomy into men and women based on their sexual differences, which, further, leads to men's domination over women. Mills (2008) does not view 'sexism' as an exclusively individual practice of discrimination in language use. Rather, she adds that major social and institutional forces of power asymmetry also play their pivotal role in producing and promoting sexist attitudes and practices. She looks at sexism linguistically and pragmatically.

\section{Gender Discrimination: A Critical Overview}

Patriarchal society provides a base for gender discrimination. Inequality and injustice in gender relations are the results of the existing dominant perceptions about gender dichotomy and gender ideology. Lazar (2007) explains and extrapolates that "social structures of patriarchy systematically privilege men as a social group, and disadvantage, exclude, and disempower women as a social group" (Lazar, 2007, p. 145). For her, overt "forms of gender asymmetry or sexism, traditionally, have included exclusionary gate-keeping social practices, physical violence against women, and sexual harassment and denigration of women" (Lazar, 2007, p. 148). Multi-dimensional study of sexism leads Mills (2008) to argue that it is realized directly or indirectly at the individual and institutional levels. For her, overt sexism can be explored in language use directly through the analysis of linguistic markers or "presupposition, which has historically been associated with the expression of discriminatory opinions about women, which signals to hearers that women are seen as an inferior group in relation to males" (Mills, 2008, p. 11). Sexism is diverse, pragmatic, depending upon the contexts of its usage/practice. According to her, sexism is an intentional practice in language use which can be declared as sexist through the analysis of language use and/or its context. Her views reveal the local and social model of sexism in their specific and general societal contexts. These sexism and levels are related to each other has been called 
sexism on the individual level, while partly affects the institutional sexist attitudes, behaviors, and etc. She (like Lazar (2007) acknowledges the role of patriarchal structures in gender discrimination. For, Lazar and Kramarae, (2011), the asymmetries of gender, and power are causes of gender discrimination. Direct or overt realization of sexism is rare in the social, and political institutions on account of feminist movement and campaign. For Eckert (1989), the traditional gender ideology dichotomizes people into men and women on account of the so-called perceived gender roles and disparities.

Eckert (1989) has offered more complicated operation of gender for gender oppression as compared to other forms of oppressions. According to Allen (2009), the Foucaultian concept of subjection is a central topic in Butler's works. Domination and subordination are the integral elements of subjection as a form of power. In Allen's view $(2009$, p. 300), the approach of poststructuralism not only examines "the relationship between gender difference and relations of dominance and subordination (as second-wave feminists attempted to do as well), it also suggests that the category of gender, itself, is power-laden, that it can serve as a mechanism of exclusion." Allen refers to Butler, (1995) who argues that "Identity categories are never merely descriptive, but always normative, and as such, exclusionary" (cited in Allen, 2009, p. 300). Eckert (1989) sheds light on how women are more status-conscious than men, but he supports the argument that "women are more status-bound than men" (1997, p. 217 ; italics in original).

There are diverse ways used by men and women for struggling to establish their social status and identity. The mentioned struggle over status is more explicit and vivid in cases of their isolated gender roles and their challenged gender identities. It is, generally, suggested that women, who are powerless, should build and recognize their due status through language (Eckert, 1989). Shabir's (2018) work on A Thousand Splendid Suns reveals the root causes of gender discrimination in Afghanistan. He concludes that there are socio-cultural (e.g. gender stereotyping, patrilineality, patrilocality, conservative and traditional mindset and ideology); economic (poverty, especially women's economic dependence on men); political (e.g. instability of and mismanagement in judiciary and political system; the rise of Taliban and Mujahedeen); ideological (extremist, sectarian and ethnic ideologies); geo-political (e.g. foreign aggression in Afghanistan due to its geo-political significance) factors involved behind gender discrimination.

\section{Theoretical and Analytical Perspective: Lazar's Version of Feminism}

The feminist approach to critique gendered discourses is considered both as a theory and practice (method). It was introduced by Lazar (2005). Similarly, this approach was also effectively adapted

by Sunderland (2004) and Lehtonen (2007) for studying children's fiction and children's fantasy fiction respectively. Lazar's feminist approach seeks egalitarianism, social justice, emancipation and transformation of/for feminine gender. Its emergence is "a timely contribution to the growing body

of feminist discourse literature, particularly in the field of gender and language" (Lazar, 2007, p. 144).

Lehtonen sheds light on how Lazar's version of feminism is applicable to the analysis of novels in these words: "fictional 
texts are a form of language use - although a highly specialized one - and a site where gendered identities are discursively constructed, there is no reason per se why feminist linguistic analysis could not deal also with fictional texts" (Lehtonen, 2007, p. 3; italics in original).

The prime objective of this approach is to study "discourses which sustain a patriarchal social order - relations of power that systematically privilege men as a social group, and disadvantage, exclude, and disempower women as a social group" (2007, p. 145). Social emancipation, egalitarianism and empowerment of women are some of the aims of this approach.

Unlike this, social theory views gender identity as social relation(s) among the subjects in certain contexts wherein gender is determined in social relations. Butler's (1990, p. 25) non-essentialist or anti-foundationalist view of gender sees gender as "culturally constructed; hence, gender is neither the causal result of sex nor as seemingly fixed as sex." According to her, gender is not subject of a deed or a set of universal attributes. Rather, it is performative. Gender is considered as a discursive performance that is expressed in an ongoing interaction wherein the subjects emerge as a result of that performance (Butler, 1990). She adds that "There is no gender identity behind the expressions of gender; that identity is performatively constituted by the very "expressions" that are said to be its results" (1990, p. 25). Her focus is more on the deed or performance than the doer of that deed. Lazar argues that "overt forms of gender asymmetry or sexism, traditionally, have included exclusionary gate-keeping social practices, physical violence against women, and sexual harassment and denigration of women. Such overt manifestations of power . . . remain a reality for women in many societies, even where there is legislation against blatant gender discrimination" (2007, p. 148).

\section{Research Method for Data Analysis: Feminist Stylistics}

It is pertinent to argue that Sara Mills's (1995) feminist stylistics is a viable research method for exploring various layers of explicature and implicature of gendered discourses in their textual and social contexts. Feminist stylistics is an amalgamation of stylistics (as a research method) and feminism (as a theory). Feminist stylistic analysis at the phrase/sentence level is related to the semantic and pragmatic analysis of various phrases and syntactic structures used in a discourse. At this level of analysis, the analyst investigates certain phrases (e.g. ready-made phrases and metaphoric phrases); patterns of transitivity; presuppositions; sexist jokes/humors; sentences expressing certain ideology. Analysis at this level focuses on the explicit and implicit meanings of the language used to depict characters/roles, fragmentation of the female body (through words and images) with male focalization (representation of the female as an object for the male gaze), various schemata, e.g. sexist schemata, drawn upon to represent women.

\section{Data Analysis and Discussion}

The entire analysis of discourses on gender discrimination in "A Thousand Splendid Suns" exposes gender discrimination against Mariam and Laila by Rasheed and the Mujahideen in restrictive patriarchal system. Nevertheless, Mariam was also othered by her father and her stepmothers. Her harami ('illegitimate') gender (identity) was a source and emblem of shame on their honor and identity. 'Harami' was a title addressed to Mariam at the domestic and social levels. Nana, her mother, in anger and frustration also used to address her as 
a "clumsy little harami" (Hosseini, 2007, p. 3). Having experienced the odds and adversities of life, Mariam understood that 'harami' means "an illegitimate person who would never have legitimate claim to the things other people had, things such as love, family, home, acceptance" (2007, p. 4). It is another example of discrimination when Jalil (Mariam's father) and his wives hold Nana solely responsible for forcing Jalil for an unlawful sexual intercourse. She voices her complaint against this sort of discrimination thus: "This is what it means to be a woman in this world" $(2007$, p. 6$)$. Nana, further, voices gender discrimination through her expressions: "Like a compass needle that points north, a man's accusing finger always finds a woman. Always;" and "To Jalil and his wives, I was a pokeroot. A mugwort. You [Mariam], too" (2007, p. 7).

Feminist stylistic analysis of the selected passage/lines at the phrase/sentence and discourse levels (2007, p. 26) reveals that Jalil's family excluded Mariam, and discarded her as a root. Nana's view was true in addressing Mariam in these words: "A man's heart is a wretched, wretched thing, Mariam. It isn't like a mother's womb. It won't bleed, it won't stretch to make room for you"; and that "when I'm gone, you'll have nothing. You are nothing!" (2007, p. 26). Another instance of deceitful discrimination against Mariam is when she was forced into a premature marriage after her mother's suicide. Jalil's family did not allow Mariam to get her education whereas her half sisters were not only educated, but also not asked to marry Rasheed. Feminist stylistic analysis of passage/lines (2007, pp. 44-45) at the phrase/sentence and discourse levels exposes the clever and planned way of Jalil's wives to get rid of her as a cursed burden on them. This burden was depicted in these words: "As you are now to us" (2007, p. 45). Feminist stylistic analysis also shows Rasheed's vilely sexist language and attitude for his wives. He used to treat them as his workers, slaves and lust-gratifying tools. He also set an example of discrimination between Mariam and Laila based on their sexuality and appearance. His address to Mariam was "a deha$t i$," "a village girl," a girl below the level of a villager (2007, p. 199). He considered her as "a good worker, and without pretensions" (2007, p. 199).

Applying feminist stylistic analysis at the word level on the selected words reveals how Rasheed used to address Mariam as a 'Volga,' an old-fashioned car and Laila as a 'Benz,' a new brand car. Rasheed commented on their appearance thus: "If she were a car, she would be a Volga" and "you, on the other hand, would be a Benz. A brand-new, first-class, shiny Benz" (2007, p. 199). Rasheed's overt sexism is realized through his address to Laila as "the queen, the malika," and asking Mariam to serve her in a better way. His overt sexism is exposed in these words: "one does not drive a Volga and a Benz in the same manner" (2007, p. 200). Feminist stylistic analysis of the passage/lines (2007, pp. 215-216) spotlights Laila's denial to Rasheed's offer for sex, and how Rasheed rushes angrily into Mariam's room, and how he blames and beats her badly with a leather belt. The scandalous scene focuses on how Mariam was afraid of Rasheed's masochistic power abuse and devilish discrimination against her through the narrator's voice: "Over the years, Mariam had learned to harden herself against his scorn and reproach, his ridiculing and reprimanding. But this fear she had no control over" (2007, p. 215). Aziza was also an illegitimate child, and Rasheed showed a dastardly and inhuman attitude to her. Rasheed snubbed her vilely thus: 
"Get off my heels!", he snapped, making a shooing motion with his gun. "Stop following me! And you can stop twirling your wrists like that. I'm not picking you up. Go on! Go on before you get stepped on" (2007, p. 227). The Afghan Mujahideen used to maintain order. However, their biased law usually favored men, and the same order was abused as a weapon for discriminating against women. When they tried to flee from Rasheed's prison house of betrayed injustice and cruelty, they were without their 'mehram.'

Another exhibition of the Taliban's gender discrimination is that when a young Talib beats Laila with a radio antenna accompanied by his sexist language: "I see you again, I'll beat you until your mother's milk leaks out of your bones" (2007, p. 286). Observing Laila's immanent death at the hands of Rasheed, Mariam killed him. Afterwards, Laila requests her not to surrender to the Taliban and to escape to a protected place in Pakistan, but she disagrees with her by discursively exposing the Taliban's sexism in her voice: "When they [the Taliban] do, they'll find you as guilty as me. Tariq too" (2007, p. 318). Overt sexism of the Taliban against the imprisoned women is derisively dotted in voice of the narrator as the Talib guards "leered in, with their inflamed eyes and wolfish smiles, that they muttered indecent jokes to each other about them" (2007, p. 321). Feminist stylistic analysis of a passage (2007, p. 329) demonstrates how the discourse-producer shows his sympathy for Mariam, who was executed by the Taliban. His remark of irony strikingly reveals his perspective of resistance against the sexist Taliban: "It was not so bad, Mariam thought, that she should die this way. Not so bad. This was a legitimate end to a life of illegitimate beginnings" (2007, p. 329).

\section{References:}

1. ALLEN A (2009) Gender and power. In Stewart R. Clegg \& M. Haugaard (Eds.), Power: A Reader (pp. 293-309). London: SAGE Publications Ltd.

2. BUTLER J (1990) Gender trouble: Feminism and the subversion of identity. New York: Routledge.

3. ECKERT P (1989) The whole woman: Sex and gender differences in variation. Language Variation and Change, 1(3), 245-267. doi:10.1017/S095439450000017X.

4. EGGERS D (2007) Khaled Hosseini's splendid suns second act (interview). Retrieved on January 10, 2015, from www. powells.com/blog/interviews/khaled-hosseinis-splendid-second-act-bydave/sociolinguistics (pp. 139-152). London: SAGE Publications Ltd.

5. HALLIDAY M A K (1978) Language as social semiotic: The social interpretation of language and meaning. London: Edward Arnold.

6. HOSSEINI K (2007) A thousand splendid suns. London: Bloomsbury Publishing.

7. LAZAR M M (2005) Politicizing gender in discourse: Feminist cda as political perspective and praxis. In M. M. Lazar (Eds.), Feminist critical discourse analysis: Gender, power and ideology in discourse (pp. 1-28). Basingstoke: Palgrave Macmillan.

8. LAZAR M M (2007) Feminist critical discourse analysis: Articulating a feminist discourse praxis. Critical Discourse Studies, 4(2), 141-164.

9. LAZARMM,KRAMARAEC(2011)Gender and power in discourse. In Teun A. van Dijk (Eds.),Discoursestudies: Amultidisciplinary introduction (pp. 217-240). London: SAGE Publications Ltd.

10. MECHANIC M (2009) Khaled Hosseini, Kabul's splendid suns (extended interview). Retrieved on January 11, 2015, from 
www.motherjones.com/media/2009/05/mojo-interview-khaledhosseini-kabuls-splendid-son-extended-interview.

11. MILLS S (1995) Feminist stylistics. London: Routledge.

12. MILLS S (2008) Language and sexism. Cambridge: Cambridge University Press.

13. RICHARDS A (2007) "Khaled hosseini: A thousand splendid suns." Retrieved on January 10, 2015, from www.mostlyfiction. com/world/hosseini.htm .

14. SETHNA R (2003) Interview: Khaled hosseini. Retrieved on January 11, 2015, from www.newslinemagazine. com/2003/11/interview-khaled-hosseini/. SHABIR M (2018) A critique of gender ideology and discrimination in a thousand splendid suns. (MPhil dissertation submitted to Qurtuba University of Science and Technology). 60-84.

15. SUNDERLAND J (2006) Language and gender. An advanced resource book. London: Routledge Publishing.

16. YARDLEY J (2007) A thousand splendid suns by Khaled Hosseini (review). Retrieved on January 10, 2015, from www. washingtonpost.com/wp 423dyn/content/article/2007/05/17/AR20070517019 32.html 